\title{
HUBUNGAN ANTARA MINAT MENGIKUTI PEMBELAJARAN PBL (PROBLEM BASED LEARNING) DENGAN MOTIVASI MENINGKATKANPRESTASI PADA MAHASISWA TINGKAT I AKADEMI KEPERAWATANPANTI KOSALA SURAKARTA
}

\author{
Oleh : \\ Endang Dwi Ningsih ${ }^{1}$, Ratna Indriati ${ }^{2}$, Magdalena Putri S. ${ }^{3}$
}

\begin{abstract}
Background. Problem Based Learning (PBL) is an instructional model that the students involved in problem solving by scientific methods, so the students learn the knowledge related to the issued also the problem solving skill as well.

The purpose of the study was to determine the relation between interest in learning the PBL with motivation in increasing the learning achievement on the first year students of the Nursing Academy Panti Kosala Surakata.

Subjects of the study by correlation method was held on April-Mei 2013, the subject were 140 first year student of the Nursing Academy Panti Kosala Surakarta.

The results shows: 1 . There was any relation between interes in learning the PBL with motivation in increasing the learning achievement on the first year students of the Nursing Academy panti Kosala Surakarta, analized by $X^{2}$ count $>X^{2}$ table $(188,321>13,277)$ with a significant level 0,01 (1\%). 2. The determination coefficient value is 0,796 indicate that interested in learning the PBL influence to the motivation in increasing learning achievement as $79,6 \%$ and the rest as $20,4 \%$ influenced by the other else variables non model.
\end{abstract}

Keyword : Interested in learning and the motivation in increasing learning.

\section{PENDAHULUAN}

Dalam memasuki millenium ketiga dengan tuntutan global perlu adanya tuntutan penugasan dan penerapan ilmu pengetahuan dan teknologi. Demikian pula pendidikan tinggi perlu memenuhi tuntutan-tuntutan tersebut. Pendidikan seringkali dijelaskan melalui sudut pandang masing-masing orang, ahli sosiologi akan mengartikan pendidikan sebagai usaha pewarisan dari generasi ke generasi, pakar antropologi mengartikan pendidikan sebagai usaha pemindahan pengetahuan dan nilai-nilai kepada generasi berikutnya, sedang ahli

\begin{abstract}
ekonomi akan mengartikan pendidikan sebagai suatu usaha penanaman modal sumber daya manusia untuk membentuk tenaga kerja dalam pembangunan bangsa. Pendidikan harus dijelaskan secara integral, lengkap dan utuh, dengan sudut pandang yang sistemik, pendidikan dapat diidentifikasikan sebagai suatu sistem yang utuh dengan bagian-bagiannya berinteraksi satu sama lain. Dalam hal ini pendidikan adalah suatu kesatuan yang utuh.
\end{abstract}

Pendidikan juga dapat diartikan sebagai keseluruhan karya insani 
yang terbentuk dari bagian-bagian yang mempunyai hubungan fungsional dalam usaha mencapai tujuan akhir. Sebagai sistem, pendidikan berada dalam suatu supra sistem dan sub sistem. (Pannen dan Sadjati, 2001) Sistem secara sederhana dapat diidentifikasikan sebagai suatu kesatuan dari berbagai elemen atau bagian-bagian yang mempunyai hubungan fungsional dan berinteraksi secara dinamis untuk mencapai hasil yang diharapkan. Pendidikan sebagai suatu sistem memperoleh masukan dari supra sistem dan memberikan hasil (keluaran) bagi supra sistem. Masukan yang diperoleh dari supra sistem terdiri dari tata nilai, cita-cita, dan norma-norma yang terdapat dalam masyarakat. (Pannen dan Sadjati, 2001).

Sistem Pendidikan Nasional
Indonesia merupakan satu
keseluruhan yang terpadu dari
semua satuan dan kegiatan
pendidikan yang berkaitan satu
dengan yang lainnya untuk
mengusahakan tercapainya tujuan
Pendidikan Nasional yang
berdasarkan Pancasila dan UUD 45. Pendidikan Nasional Indonesia bertujuan mencerdaskan kehidupan bangsa dan mengembangkan manusia Indonesia seutuhnya, yaitu manusia yang beriman dan bertaqwa terhadap Tuhan Yang Maha Esa dan berbudi pekerti luhur, memiliki pengetahuan dan keterampilan, kesehatan jasmani dan rohani, kepribadian yang mantap dan mandiri serta rasa tanggung jawab kemasyarakatan dan kebangsaan. Pendidikan dalam rangka untuk mewujudkan masyarakat Indonesia yang baru, tentunya mengalami berbagai hambatan dan tantangan. Tantangan-tantangan tersebut ada yang berasal dari dalam internal, antara lain masalah kesatuan bangsa, demokratisasi pendidikan, desentralisasi manajemen pendidikan dan kualitas pendidikan. Selain itu terdapat tantangan global yaitu pendidikan yang kompetitif dan inovatif. Kemampuan berkompetensi dihasilkan oleh pendidikan yang kondusif dan efektif ( Sutadi, 1996) Suatu sistem pendidikan dapat juga menghasilkan tenaga-tenaga pemikir yang berkembang, tetapi apabila tidak inovatif maka kemampuan berfikirnya tidak akan mendapat makna di dalam kehidupan bersama.

Pembelajaran konvensional yang sifatnya searah yaitu dari dosen ke mahasiswa dan mahasiswa hanya pasif menerima materi, sekarang dianggap cara yang kurang tepat lagi. Diperlukan metode pembelajaran yang lebih efektif yaitu membuat mahasiswa lebih aktif dalam proses pembelajaran. Salah satu metode pembelajaran yang dapat digunakan adalah metode PBL (Problem Based Learning) (Aisyah, 2008) Pembelajaran berbasis PBL (Problem Based Learning), merupakan salah satu model pembelajaran inovatif yang dapat memberikan kondisi belajar aktif kepada peserta didik. PBL (Problem Based Learning) adalah suatu model pembelajaran yang melibatkan mahasiswa untuk memecahkan suatu masalah melalui tahap-tahap metode ilmiah sehingga mahasiswa dapat mempelajari pengetahuan yang berhubungan dengan masalah tersebut dan sekaligus memiliki keterampilan untuk memecahkan masalah (Aisyah, 2008) Pembelajaran PBL (Problem Based Learning) tidak akan berhasil jika tidak ada minat dari peserta didik. Minat merupakan kekuatan dari dalam dan tampak dari luar sebagai gerak-gerik dan dalam menjalankan fungsinya berhubungan dengan pikiran dan perasaan ( Purwanto, 1998) Pada saat seseorang sudah menentukan 
pilihan keputusan dari suatu minat maka keputusan inilah yang melandasi motivasi orang tersebut untuk mencapai tujuan. Motivasi artinya mendorong untuk berbuat atau beraksi. Motivasi adalah semua hal verbal, fisik atau psikologis yang membuat seseorang melakukan sesuatu sebagai respon. Motivasi inilah yang mendorong seseorang untuk berperilaku, beraktifitas dalam mencapai tujuan dan motivasi itu bersifat alami. (Widayatun, 1999). Motivasi adalah faktor-faktor yang ada dalam diri seseorang yang menggerakkan, dan mengarahkan perilakunya untuk memenuhi tujuan tertentu. (Purwanto, 1999)

Akademi Keperawatan Panti Kosala Surakarta sebagai lembaga pendidikan yang mengemban tugas pembelajaran merupakan salah satu lembaga pendidikan yang mulai menerapkan metode PBL (Problem Based Learning). Pembelajaran PBL mulai diterapkan pada mahasiswa Tingkat I. Motivasi dalam meningkatkan prestasi dapat dilihat dengan kehadiran dan keikutsertaan (minat) mahasiswa saat pembelajaran serta pada diskusi di luar jam pembelajaran metode PBL ini. Namun di sisi lain muncul beberapa keluhan tentang sistem pembelajaran $\mathrm{PBL}$ antara lain mahasiswa tidak mengerti, mahasiswa menjadi lelah, tetapi sebagian mahasiswa merasa sangat senang dengan sistem pembelajaran tersebut. Minat mahasiswa terhadap sistem pembelajaran PBL memiliki peran penting dalam memotivasi prestasi mahasiswa. Terkait dengan hal-hal tersebut di atas, maka penulis tertarik untuk meneliti mengenai "Hubungan antara minat mengikuti sistem pembelajaran PBL (Problem Based Learning) dengan motivasi meningkatkan prestasi pada mahasiswa tingkat I Akademi Keperawatan Panti Kosala Surakarta.

\section{METODE PENELITIAN}

Penelitian ini menggunakan metode penelitian korelasi. Penelitian korelasi adalah penelitian yang mengkaji hubungan antar variabel. Peneliti dapat mencari, menjelaskan suatu hubungan, memperkirakan, menguji berdasarkan masalah yang ada. (Nursalam, 2001).

Dalam penelitian ini ada dua variabel yang diteliti yaitu:

1. Variabel Independent

Merupakan variabel bebas adalah variabel minat mengikuti pembelajaran PBL.

2. Variabel Dependent

Merupakan variabel terikat adalah variabel motivasi meningkatkan prestasi pada mahasiswa tingkat I Akademi Keperawatan Panti Kosala Surakarta.

\section{POPULASI, SAMPEL DAN TEKNIK SAMPLING PENELITIAN.}

1. Populasi

Populasi adalah keseluruhan dari suatu variabel yang menyangkut masalah yang diteliti (Nursalam, 2001) Populasi dalam penelitian ini adalah :

a. Seluruh mahasiswa tingkat I Akademi Keperawatan Panti Kosala sejumlah 140 orang.

b. Masih aktif dalam perkuliahan.

c. Hadir saat pengambilan data.

2. Sampel

Sampel merupakan sebagian dari jumlah karakteristik yang dimiliki oleh populasi (Nursalam, 2001). Dalam penelitian ini, peneliti menggunakan seluruh populasi sebagai responden.

3. Tehnik Sampling

Pengambilan sampel dilakukan menggunakan sampling jenuh yaitu semua anggota populasi sebagai sampel. (Nursalam, 2001). 
HASIL PENELITIAN

Penelitian ini dilakukan pada bulan April - Mei 2013 pada mahasiswa tingkat I Akademi Keperawatan Panti Kosala Surakarta yang mendapat pembelajaran Problem Based Learning (PBL) untuk mata kuliah Mikrobiologi dan Parasitologi. Jenis penelitian ini adalah survei dengan kuesioner sebagai alat pengumpulan data dengan cara memberikan daftar pernyataan tertulis dengan jawaban tertutup (Budiarto, 2001). Berdasarkan hasil penyebaran kuesioner sebanyak 140 responden pada Mahasiswa tingkat I Akademi Keperawatan Panti Kosala Surakarta yang mendapat pembelajaran PBL untuk mata kuliah mikrobiologi dan parasitologi dapat dideskripsikan sebagai berikut:

Tabel 1.

Komponen Responden Berdasarkan Jenis Kelamin

\begin{tabular}{cccc}
\hline No & $\begin{array}{c}\text { Jenis } \\
\text { Kelamin }\end{array}$ & $\begin{array}{c}\text { Jumlah } \\
\text { (orang) }\end{array}$ & $\%$ \\
\hline 1. & Laki-laki & 25 & 17,86 \\
2. & Perempuan & 115 & 82,14 \\
\hline & Total & 140 & 100 \\
\hline
\end{tabular}

Komposisi responden berdasarkan jenis kelamin pada tabel di atas menunjukkan bahwa sebagian responden adalah perempuan yang berjumlah 115 orang (82,14\%), sedangkan jumlah laki-laki berjumlah 25 orang $(17,86 \%)$.

Tabel 2.

Komposisi Kelas Responden

\begin{tabular}{cccc}
\hline No & Kelas & $\begin{array}{c}\text { Jumlah } \\
\text { (orang) }\end{array}$ & $\%$ \\
\hline 1. & I A & 48 & 34,28 \\
2. & I B & 49 & 35,00 \\
3. & I C & 43 & 30,72 \\
\hline & Total & 140 & 100 \\
\hline
\end{tabular}

Komposisi responden berdasarkan kelas pada tabel di atas menunjukkan bahwa sebagian responden adalah kelas I A yang berjumlah 48 orang $(34,28 \%)$, kelas I B berjumlah 49 orang $(35,00 \%)$, sedangkan jumlah kelas I C berjumlah 43 orang (30,72\%).

Hasil Penelitian:

1. Uji Validitas Instrumen

Uji validitas digunakan untuk mengetahui bahwa setiap pernyataan dinyatakan valid atau tidak dengan melihat hasil $r$ hitung dan membandingkannya dengan $r$ tabel, dengan alpha $1 \%$ $(\alpha=0,01)$, bila $r$ hitung lebih besar dari $r$ tabel dan signifikasi lebih kecil dari 0,01 maka pernyataan dinyatakan valid. Validitas dengan menggunakan product moment dari Pearson diperoleh hasil sebagai berikut:

a. Uji Validitas Instrumen Minat Mengikuti Pembelajaran PBL:

Tabel 3.

\begin{tabular}{ccccc}
\hline $\begin{array}{c}\text { Pernya- } \\
\text { taan }\end{array}$ & $\begin{array}{c}\mathbf{R} \\
\text { hitung }\end{array}$ & $\begin{array}{c}\mathbf{R} \\
\text { tabel }\end{array}$ & $\begin{array}{c}\text { Signifi- } \\
\text { kasi }\end{array}$ & $\begin{array}{c}\text { Kesim- } \\
\text { pulan }\end{array}$ \\
\hline$\times 1$ & 0,583 & 0,210 & 0,000 & valid \\
\hline$\times 2$ & 0,365 & 0,210 & 0,000 & valid \\
\hline$\times 3$ & 0,554 & 0,210 & 0,000 & valid \\
\hline$\times 4$ & 0,419 & 0,210 & 0,000 & valid \\
\hline$\times 5$ & 0,646 & 0,210 & 0,000 & valid \\
\hline$\times 6$ & 0,582 & 0,210 & 0,000 & valid \\
\hline$\times 7$ & 0,499 & 0,210 & 0,000 & valid \\
\hline$\times 8$ & 0,606 & 0,210 & 0,000 & valid \\
\hline$\times 9$ & 0,500 & 0,210 & 0,000 & valid \\
\hline$\times 10$ & 0,549 & 0,210 & 0,000 & valid \\
\hline
\end{tabular}

Hasil pengujian Validitas Instrumen Minat Mengikuti Pembelajaran PBL pada Tabel 3. di atas menunjukkan bahwa dari 10 item pernyataan dinyatakan valid, karena $r$ hitung lebih besar $r$ tabel, sehingga 10 pernyataan dapat digunakan dalam pengambilan data. 


\section{b. Uji Validitas instrumen motivasi meningkatkan prestasi}

Tabel 4.

\begin{tabular}{|c|c|c|c|c|}
\hline $\begin{array}{c}\text { Pernya- } \\
\text { taan }\end{array}$ & $\begin{array}{c}\mathbf{R} \\
\text { hitung }\end{array}$ & $\begin{array}{c}\mathbf{R} \\
\text { tabel }\end{array}$ & $\begin{array}{c}\text { Signifi- } \\
\text { kasi }\end{array}$ & $\begin{array}{c}\text { Kesim- } \\
\text { pulan }\end{array}$ \\
\hline Y1 & 0,363 & 0,210 & 0,000 & \\
\hline Y2 & 0,299 & 0,210 & 0,000 & valid \\
\hline Y 3 & 0,520 & 0,210 & 0,000 & valid \\
\hline Y 4 & 0,494 & 0,210 & 0,000 & valid \\
\hline Y 5 & 0,493 & 0,210 & 0,000 & valid \\
\hline Y 6 & 0,594 & 0,210 & 0,000 & valid \\
\hline Y 7 & 0,543 & 0,210 & 0,000 & valid \\
\hline Y 8 & 0,407 & 0,210 & 0,000 & valid \\
\hline Y 9 & 0,519 & 0,210 & 0,000 & valid \\
\hline Y 10 & 0,486 & 0,210 & 0,000 & valid \\
\hline & \multicolumn{4}{|c|}{$\begin{array}{l}\text { Hasil pengujian } \begin{array}{l}\text { Validitas } \\
\text { Motivasi }\end{array} \\
\text { Instrumen } \\
\text { Meningkatkan Prestasi pada } \\
\text { table 4. di atas menunjukkan } \\
\text { bahwa dari } 10 \text { item } \\
\text { pernyataan dinyatakan valid, } \\
\text { karena } r \text { hitung lebih besar } r \\
\text { tabel Sehingaa }\end{array}$} \\
\hline
\end{tabular}

2. Uji Chi Square

Dari penelitian yang telah dilakukan pada mahasiswa tingkat I Akademi Keperawatan Panti Kosala Surakarta mengenai hubungan antara minat mengikuti pembelajaran PBL dengan motivasi meningkatkan prestasi dapat diuraikan sebagai berikut:

a. Tingkat minat mengikuti pembelajaran

Tabel.5.

Distribusi Responden Berdasarkan Minat Mengikuti

\begin{tabular}{ccc}
\multicolumn{3}{c}{ Pembelajaran PBL } \\
\hline \multicolumn{1}{c}{ Minat } & $\mathrm{F}$ & $\%$ \\
\hline Tinggi & 60 & 42,87 \\
Sedang & 75 & 53,56 \\
Rendah & 5 & 3,57 \\
\hline Jumlah & 140 & 100 \\
\hline
\end{tabular}

b. Tingkat motivasi mahasiswa dalam meningkatkan prestasi

Tabel 6.

Distribusi Responden

Berdasarkan Motivasi

Meningkatkan Prestasi

\begin{tabular}{lcc}
\hline Motivasi & $\begin{array}{c}\text { Frekuensi } \\
\text { (orang) }\end{array}$ & $\%$ \\
\hline Tinggi & 60 & 42,87 \\
Sedang & 75 & 53,56 \\
Rendah & 5 & 3,57 \\
\hline Jumlah & $\begin{array}{c}140 \\
\text { orang }\end{array}$ & 100 \\
\hline
\end{tabular}

Setelah dilakukan perhitungan maka didapatkan hasil nilai $X^{2}$ hitung sebesar 188,321 dengan tingkat kemaknaan atau alpha $1 \%$ yang diambil dari 140 mahasiswa. Dari perhitungan di atas dapat diketahui bahwa nilai $X^{2}$ hitung sebesar 188,321 > $X^{2}$ tabel sebesar 13,277 , berarti bahwa $\mathrm{Ho}$ ditolak dan $\mathrm{Ha}$ diterima. Dengan demikian hasil penelitian bahwa ada hubungan antara minat mengikuti pembelajaran PBL dengan motivasi meningkatkan prestasi pada mahasiswa tingkat I Akademi Keperawatan Panti Kosala Surakarta.

3. Uji $R^{2}$

Pada Uji Koefisien determinasi $\left(\mathrm{R}^{2}\right)$ didapat nilai Adjusted $R$ Square adalah 0,796. Hal ini menunjukkan bahwa variabel independent mampu menjelaskan sebesar $79,6 \%$ terhadap variabel dependent, sedangkan sisanya sebesar 20,4\% dijelaskan oleh faktor lain diluar model.

\section{PEMBAHASAN}

Dalam pembahasan ini peneliti akan membahas hasil penelitian yang telah dilakukan yaitu tentang hubungan antara minat mengikuti 
pembelajaran $\mathrm{PBL}$ dengan motivasi meningkatkan prestasi pada mahasiswa tingkat I Akademi Keperawatan Panti Kosala Surakarta dengan jumlah responden 140 mahasiswa diketahui bahwa yang mempunyai minat dalam mengikuti pembelajaran $\mathrm{PBL}$ pada kategori tinggi sejumlah 60 orang $(42,87 \%)$, sedang sebesar 75 orang $(53,56 \%)$ dan rendah sebesar 5 orang $(3,57 \%)$. Dari hasil di atas menunjukkan bahwa minat mahasiswa pada kategori sedang sampai kategori tinggi relatif baik sehingga dapat disimpulkan bahwa mahasiswa senang dalam mengikuti pembelajaran dengan Sistem PBL, hal ini sesuai yang disampaikan oleh Purwanto (1999) bahwa minat berhubungan dengan pikiran dan perasaan, perbuatan minat memilih danmengambil keputusan disebut keputusan kata hati. Sedang yang mempunyai motivasi meningkatkan prestasi pada kategori tinggi sebesar 60 orang $(42,87 \%)$, sedang sebesar 75 orang $(53,56 \%)$ dan rendah sebesar 5 orang $(3,57 \%)$. Demikian pula yang tergambar pada hasil motivasi bahwa motivasi mahasiswa pada kategori sedang sampai dengan kategori tinggi relatif baik, hal ini menunjukkan bahwa mahasiswa menyadari pentingnya berprestasi dengan meningkatkan diri melalui proses pembelajaran terutama melalui metode PBL, sebagaimana yang dikutip oleh Purwanto (1999) bahwa dengan motivasi manusia akan bersungguhsungguh melakukan kegiatan karena menyadari pentingnya suatu perilaku dan dirasakan sebagai suatu kebutuhan.

Hubungan antara minat mengikuti pembelajaran PBL dengan motivasi meningkatkan prestasi pada mahasiswa tingkat I Akademi Keperawatan Panti Kosala Surakarta menunjukkan ada hubungan terbukti dengan analisa Chi Square didapatkan $\mathrm{X}^{2}$ hitung sebesar $188,321>X^{2}$ tabel sebesar 13,277 yang diambil dari 140 mahasiswa dengan tingkat kemaknaan atau alpha sebesar $1 \%$ sehingga $\mathrm{Ho}$ ditolak, Ha diterima .

Keberadaan minat pada diri individu dapat dikatakan merupakan suatu hasil dari serangkaian proses. Jika seseorang berminat terhadap sesuatu, maka yang pertama kali dialami adalah pengarahan terhadap objek, subjek atau aktivitas yang merupakan rangsangan bagi diri individu. Berbagai rangsangan tersebut dapat berbentuk bendabenda atau suatu kegiatan. Dari pengenalan ini, akan timbul perasaan sadar bahwa objek, subjek atau aktivitas tersebut bermanfaat bagi dirinya, maka pada saat itu akan diikuti perasaan senang sehingga menimbulkan motivasi bagi dirinya. Jadi minat memiliki hubungan dengan timbulnya motivasi. Hal ini sesuai dengan teori yang dikemukakan pada artikel www.bintangbangsaku.com (2009) yang mengemukakan bahwa minat pada sesuatu akan menimbulkan motivasi untuk meningkatkan kemampuan dalam bidang tersebut. Adapun faktor timbulnya minat yang terdiri atas dorongan dari dalam untuk menghasilkan sesuatu yang baru, motif sosial yaitu minat untuk mengembangkan diri atau memperoleh penghargaan dan faktor emosional berupa perasaan puas bila dapat meningkatkan diri mendorong seseorang untuk memiliki minat pada sesuatu hal/ aktifitas (Yuwono, 2008) Hal ini sangat terkait dengan tujuan pembelajaran yakni mencapai perkembangan optimal pada aspek kognitif, afektif dan psikomotoris, untuk mencapai tujuan tersebut maka harus memiliki minat pada kegiatan belajar.

Besarnya pengaruh variabel minat mengikuti pembelajaran PBL 
terhadap variabel motivasi meningkatkan prestasi adalah sebesar 0,796 (adjusted $R^{2}$ ) artinya bahwa motivasi meningkatkan prestasi pada mahasiswa tingkat I Akademi Keperawatan Panti Kosala Surakarta dipengaruhi oleh minat mengikuti pembelajaran PBL sebesar $79,6 \%$. Sedangkan sisanya $20,4 \%$ dipengaruhi oleh variabel lain. Sesuai dengan ciri-ciri dalam pembelajaran $\mathrm{PBL}$ antara lain : pembelajaran berpusat pada masalah yang mungkin dihadapi di masa depan, mahasiswa bertanggungjawab pada proses pembelajaran maka mahasiswa harus aktif untuk terlibat dalam semua kegiatan (Aisyah, 2008) hal ini sesuai pada hasil yang didapat oleh peneliti bahwa minat mahasiswa akan memberi dukungan pada motivasi berprestasi yakni $79,6 \%$, dan sisanya sebesar $20,4 \%$ dipengaruhi hal-hal lainnya misalnya pola didik orang tua, lingkungan, perilaku dan kemampuan individu yang tidak dapat diuraikan secara rinci pada penelitian ini.

\section{KESIMPULAN DAN SARAN}

Dari hasil penelitian yang telah dilakukan mengenai Hubungan Minat Mengikuti Pembelajaran PBL dengan Motivasi meningkatkan Prestasi Pada Mahasiswa tingkat I Akademi Keperawatan Panti Kosala Surakarta, maka dapat disimpulkan sebagai berikut:
1. Mahasiswa
Akademi
Keperawatan

$$
\text { Panti Kosala }
$$
Surakarta yang mempunyai minat mengikuti pembelajaran PBL pada kategori tinggi sebesar 60 orang $(42,87 \%$, sedang sebesar $75 \%(53,56 \%)$ dan tingkat minat rendah sebesar 5 orang $(3,57 \%)$.

2. Mahasiswa Akademi Keperawatan Panti Kosala Surakarta yang mempunyai motivasi meningkatkan prestasi kategori tinggi sebesar 60 orang
$(42,87 \%)$, sedang sebesar 75 orang $(53,56 \%)$ dan rendah sebesar 5 orang $(3,57 \%)$.

3. Pada uji Chi Square menunjukkan bahwa $X^{2}$ hitung $>X^{2}$ tabel $(188,321$ $>13,277$ ) dengan tingkat kemaknaan $\quad 1 \%$ Dapat disimpulkan bahwa: ada hubungan antara minat mengikuti pembelajaran PBL dengan motivasi meningkatkan prestasi pada mahasiswa tingkat I Akademi Keperawatan Panti Kosala Surakarta.

4. Pada uji koefisien determinasi $\left(R^{2}\right)$ menunjukkan bahwa motivasi meningkatkan prestasi yang dipengaruhi oleh minat mengikuti pembelajaran PBL sebesar $79,6 \%$ sedangkan sisanya sebesar $20,4 \%$ dipengaruhi oleh faktor-faktor lain.

Adapun saran yang dapat peneliti sampaikan adalah :

1. Bagi Pendidik, penelitian ini diharapkan mampu mengembangkan mutu proses pembelajaran, dengan memfasilitasi baik media ataupun sarana penunjang yang lain khususnya yang berkaitan dengan keberhasilan pembelajaran PBL.

2. Bagi mahasiswa, agar mahasiswa dapat memiliki minat yang tinggi terhadap pembelajaran PBL dalam rangka meningkatkan motivasi berprestasi, serta sebagai sarana pencapaian aspek kognitif, afektif dan psikomotorik secara optimal

3. Bagi Peneliti Berikutnya, dapat memberi gambaran atau informasi untuk melakukan penelitian berikutnya. 
Keterbatasan:

Penelitian ini memiliki keterbatasanketerbatasan antara lain:

1. Penelitian hanya mengambil populasi pada mahasiswa tingkat I Akademi Keperawatan Panti Kosala Surakarta tahun 2013 sehingga hasil penelitian tidak dapat digeneralisasi.

2. Instrumen penelitian yang digunakan kepada responden hanya melalui pengisian kuesioner dan tidak melalui wawancara langsung sehingga peneliti sulit mengendalikan responden.

\section{DAFTAR PUSTAKA}

Aisyah, Winarti. Pembelajaran Melalui Metode PBL (Problem Based Learning) dalam Upaya Meningkatkan Mutu Pendidikan. 2008.

Hidayat, Azis Alimul. Riset Keperawatan dan Tehnik Penulisan IImiah. Jakarta: Salemba Medika, 2003.

Muhidin, Sambas Ali dan Abdurahman Maman. Analisis Korelasi, Regresi dan Jalur Dalam Penelitian. Bandung: CV Pustaka Setia, 2007.

Arikunto, Suharsini. Dasar-dasar Evaluasi Pendidikan. Jakarta: Bumi Aksara, 2007.

Azwar, Saifudin. Reabilitas dan Validitas. Yogyakarta: Pustaka Pelajar, 2000.

Budiarto, Eko. Biostatistika untuk Kedokteran dan Kesehatan Masyarakat. Jakarta: EGC, 2001.

\footnotetext{
Bintang Bangsaku. Artikel Pendidikan Anak Usia Dini. 2008.
}

Sutadi, Rusda Koto et.al. Belajar dan Pembelajaran. Jakarta: FKIP Semarang, 1996.

Nursalam. Pendekatan Praktis Metodologi Riset Keperawatan. Jakarta: CV Sagung Seto, 2001.

Pannen, Paulina dan Ida Malati Sadjati. Pedidikan Sebagai Sistem. Jakarta: PAU-PPAI. Universitas Terbuka, 2001.

Purwanto, Heri. Pengantar Perilaku Manusia Untuk Keperawatan. Jakarta: EGC, 1999

Suciati, Prasetyo Irawan. Teori Belajar dan Mortivasi cetakan V tahun 2005. Jakarta: PAU-PPAI, Universitas Terbuka, 2005.

Sugiyono. Statistika untuk Penelitian. Bandung: Alfabeta, 2005.

Widayatun, Tri Rusmi. IImu Perilaku M.A. 104. Jakarta: CV Sagung Seto, 1999.

Yuwono. "Pengertian Minat". URL: http:/creasoft.Files.wordpress.co $\mathrm{m} / 2008 / 04 / 2$ minat.2008.

1 Dosen AKPER Panti Kosala Surakarta.

2 Dosen AKPER Panti Kosala Surakarta.

3 Mahasiswa AKPER Panti Kosala Surakarta 